Abbreviated Key Title: Sch J Agric Vet Sci

ISSN 2348-8883 (Print) | ISSN 2348-1854 (Online)

Journal homepage: https://saspublishers.com

\title{
Determination of Critical Weed Competition Period for Stevia rebaudiana Cultivation
}

\author{
Dejene Tadesse $^{1^{*}}$, Ano Wariyo ${ }^{1}$
}

${ }^{1}$ Ethiopian Institute of Agricultural Research Wondogenet Agricultural Research Center, P. O. Box 198 Shashamene, Ethiopia

DOI: $10.36347 /$ sjavs.2022.v09i01.002

| Received: 15.11.2021 | Accepted: 18.12.2021 | Published: 30.01.2022

*Corresponding author: Dejene Tadesse

Email: dejenebanjaw@gmail.com

Abstract

Original Research Article The experiment was conducted during $2019 / 2020$ at Wondogenet agricultural research center, Sidama region Ethiopia.
It was initiated to find a critical weed competition period for Stevia rebaudiana production as weed management plays
a great role in agriculture. The experiment was arranged in a randomized complete block design (RCBD) and
consisted of three replication and fourteen treatments. Stevia rebaudiana growth and yield, as well as weed data, were
assessed during the experiment and subjected to ANOVA using SAS computer software version 9.3 , and differences
between means were assessed at 5\% probability level. Stevia plant height, branch number, and leaf yield were affected
significantly due to treatments effects. Weed-free season treatment showed significantly higher stevia fresh yield (6.1
ton/ha) and dry yield ( 1.20 ton/ha) which was similar to the significantly higher results of the weedy for fifteen days
after transplanting. Variation in the weedy period from fifteen days after transplanting (15DAT) to thirty days after
transplanting (30DAT) resulted in $33.27 \%$ fresh stevia leaf yield reduction and $44.40 \%$ dry stevia leaf yield reduction.
Weedy season treatment was used as a check and showed significantly lower stevia leaf yield which was also similar
to the results of the weedy period for ninety days after transplanting (90DAT). On the other hand, the weedy period for
fifteen days after transplanting (15DAT), the weed-free period for ninety days after transplanting (90DAT), and weed-
free season treatments showed similar significantly lower weed density. An increase in the weedy period showed
higher weed density and weed biomass results. Therefore, as weeds greatly affect stevia growth and yield, early
weeding at $15 \mathrm{DAT}$ is important and recommended based on the present finding, however, for comprehensive results
the experiment should be repeated over site and year.
Keywords: Stevia, weed-completion, weed-density.
Copyright $\odot \mathbf{2 0 2 2}$ The Author(s): This is an open-access article distributed under the terms of the Creative Commons Attribution 4.0 International
License (CC BY-NC 4.0) which permits unrestricted use, distribution, and reproduction in any medium for non-commercial use provided the original
author and source are credited.

\section{INTRODUCTION}

Stevia (Stevia rebaudiana Bertoni) is a small perennial herb that belongs to the Asteraceae family of the genus Stevia. Stevia is known and grown largely in South and Central America and Asian countries as a natural sweetener (Hossain et al., 2017). Stevia is grown best in semi-humid subtropical climatic conditions. Though its stem, seed, and flower are important parts, the main economic part of the stevia plant is the leaf. The leaves are the source of sweet glycosides and have industrial importance. Stevia is considered to be the best alternative source of sugar especially for diabetes patients (Antonie, 2000). Many medicinal benefits of stevia have been reported so far. For instance, Bhosle (2000) reported as stevia is used to regulate blood pressure induces the pancreas to produce more insulin, and also acts as a bactericidal agent. The main chemical component of stevia is stevioside which is used to improve body energy levels, strengthen the immune system, stimulate mental activity, and help in withdrawing tobacco and alcohol addiction. Stevia growth and yield are governed by many abiotic and biotic factors. Soil type, weed, genotype, temperature, and water are some of the factors. Soil type, weed, genotype, temperature, and water are some of the factors. According to Zaman et al., (2015) stevia yield can be influenced by variation in soil type. In addition, stevia has a poor capacity to compete with weeds during the initial growth period (Ramesh et al., 2006), and weed control practices in stevia production are important to reduce the effects of the weeds that can also make complete yield loss. Taak et al., (2020) stated about a $25 \%$ stevia yield penalty due to weed competition. Hence, an appropriate weed control technique is important in order to reduce yield loss and related increases in production costs. In Ethiopia, stevia is a medicinal plant registered in after varietal evaluation over locations and years. However, like 
other medicinal plants, the cultivation of stevia is influenced by many factors and it is important to update the necessary production package of a crop plant for growers. Hence, the present study was conducted to determine the critical weed competition period for the stevia plants. According to Zaman et al., (2015) stevia yield can be influenced by variation in soil type. In addition, stevia has a poor capacity to compete with weeds during the initial growth period (Ramesh et al., 2006) and weed control practices in stevia production are important to reduce the effects of the weeds that can also make complete yield loss. Taak et al., (2020) stated about a $25 \%$ stevia yield penalty due to weed competition. Hence, an appropriate weed control technique is important to reduce yield loss and related increases in production costs. In Ethiopia, stevia is a medicinal plant registered after varietal evaluation over locations and years. However, like other medicinal plants, the cultivation of stevia is influenced by many factors and it is important to update the necessary production package of a crop plant for growers. Hence, the present study was conducted to find the critical weed competition period for stevia plants cultivation.

\section{MATERIALS AND METHODS Site Description}

The experiment was conducted during 2019/2020 at Wondogenet agricultural research center, Sidama, Ethiopia. It is located $14 \mathrm{~km}$ from Shashamene town. Wondogenet area is known for bimodal rainfall and the nearby farmers grow mainly sugarcane
(Saccharum officinarum), chat (Catha edulis), avocado (Persea americana), enset (Ensete ventricosum), common bean (Phaseolus vulgaris), and maize (Zea mays) in multiple cropping as well as sole cropping systems.

\section{Experimental Material, Design, and Treatments}

Registered stevia (Stevia rebaudiana Bertoni) mother plant was used from Wondogenet agricultural research center's aromatic and medicinal plants maintenance site for seedling preparation using cuttings. Seedlings were prepared using a polyethylene tube of $10 \mathrm{~cm}$ diameter. The seedlings were transplanted on the main field after two months of the field establishment. The experiment was arranged in an RCBD design with three replications. A plot was prepared to have 6 rows and 6 plants in each row and a total of 36 plants. Plant spacing of $50 \mathrm{~cm}$ between rows and $40 \mathrm{~cm}$ within plants was used during the experiment. The total experiment area was $819 \mathrm{~m} 2$ and one plot size was $2.4 \mathrm{~m} * 3 \mathrm{~m}$. Spacing of 1.5 meter between the plot and 2meter between blocks were maintained. Fourteen treatments comprised of weedfree or weed interference sets and the other series consisted of allowing weed vegetation to grow for equivalent periods were used during the experiment (Table 1). Fifteen days interval was selected considering the slow growth capability and vegetation coverage of stevia (Stevia rebaudiana Bertoni) as compared to some of the fast-growing weeds in the study area.

Table 1: Treatment descriptions (DAT = represent days after transplanting)

\begin{tabular}{|l|l|c|l|}
\hline Treatment & Description & Treatment & Description \\
\hline 1 & Weed free for 15DAT & 8 & Weedy for 15DAT \\
\hline 2 & Weed free for 30DAT & 9 & Weedy for 30DAT \\
\hline 3 & Weed free for 45DAT & 10 & Weedy for 45DAT \\
\hline 4 & Weed free for 60DAT & 11 & Weedy for 60DAT \\
\hline 5 & Weed free for 75DAT & 12 & Weedy for 75DAT \\
\hline 6 & Weed free for 90DAT & 13 & Weedy for 90DAT \\
\hline 7 & $\begin{array}{l}\text { weed-infested season long (no weed } \\
\text { control) }\end{array}$ & 14 & $\begin{array}{l}\text { Weed-free season long (no weed } \\
\text { infestation); }\end{array}$ \\
\hline
\end{tabular}

\section{Data Collection}

Data for stevia (Stevia rebaudiana Bertoni) plant height $(\mathrm{cm})$, branch number per plant (count), fresh and dry leaf yield per plot were collected and converted to per hectare (ton) for analysis to find the effects of the treatments. Net plot area was considered for weed data collection. Weed density (count/plant) was recorded for each weed species, and then, fresh aboveground weed weight (g) was collected, recorded, and subjected to oven-dry at $70{ }^{\circ} \mathrm{C}$ until a constant weight was achieved (Prasad et al., 2015) and the dry aboveground weight $(\mathrm{g})$ recorded by using a digital balance (model YP20002). Weed density (count), fresh and dry aboveground data were converted to per $\mathrm{m} 2$ for analysis. 


\section{Data Analysis}

Data collected were subjected to analysis of variance (ANOVA) using SAS software version 9.3. Differences between means were assessed using the least significance difference (LSD) test at $\mathrm{P}<0.05$.

\section{RESULTS AND DISCUSSION Stevia (Stevia rebaudiana Bertoni) data Plant height (cm)}

Analysis of variance showed that stevia plant height was significantly affected by treatments (Table 2). As weedy (weed infestation period) increased from 45DAT to 60DAT, there was significantly increase in stevia plant height (Table 3) that might be due to competition for resource, such as, sun light as plants grow more in height under shade than open field conditions. It was also statistically similar with resulted obtained at weed infested season treatment.

Table 2: Analysis of variance for yield and yield components of stevia

\begin{tabular}{|l|l|l|l|l|l|}
\hline \multicolumn{5}{|c|}{ Means } \\
\hline Source & DF & PH(cm) & BN(count) & FLYPH(ton) & DLYPH(ton) \\
\hline REP & 2 & $1.88^{\text {NS }}$ & $41.17^{\text {NS }}$ & $1.53^{\text {NS }}$ & $0.07^{\text {NS }}$ \\
\hline TRT & 13 & $53.00^{* *}$ & $114.91^{* * *}$ & $6.31^{* * *}$ & $0.31^{* * *}$ \\
\hline Error & 26 & 14.75 & 18.14 & 0.36 & 0.02 \\
\hline CV & & 7.46 & 22.22 & 22.29 & 25.36 \\
\hline
\end{tabular}

$\mathrm{NS}=$ not significant; *,**, and $* * *$ significant at $\mathrm{P} \leq 0.05, \mathrm{P} \leq 0.01$ and $\mathrm{P} \leq 0.001$ probability levels respectively; $\mathrm{DF}=$ degree of freedom; REP=replication; TRT=Treatment; $\mathrm{CV}=$ Coefficient of variance

\section{Branch number (count/plant)}

Analysis of variance showed that stevia branch number per plant was significantly affected by the treatment factor (Table 2). Weed-free period throughout the growing season as well as allowing weed growth only for 15 (fifteen) days after transplanting showed significantly higher branch numbers per plant which, were 33.33 and 30.67 respectively (Table 3 ). On the other hand, weed-infested season (no weeding, control) treatment showed the lower significant branch number (8.67). The present finding showed the importance of early weeding for the development of stevia plant branches.

\section{Fresh and dry leaf yield per hectare (ton)}

Analysis of variance revealed that both fresh and dry leaf yield per hectare was significantly affected by treatments (Table 2). Both weedy for fifteen days after transplanting (15DAT) and weed-free season treatments showed a higher significant fresh and dry leaf yield per hectare (Table 3). Similar to the result for branch number per plant, weed-infested season resulted in lower significant fresh (1.18) and dry (0.26) leaf yield per hectare (Table 3). Moreover, the treatment weedy for thirty days after transplanting (30 DAT) showed the second significant higher both fresh and dry leaf yield per hectare compared to weedy for 45DAT, 60DAT, 75DAT, and 90DAT treatments for both fresh and dry leaf yield per hectare. Hence, allowing weeds growth for 15 days after transplanting and then removing weeds from the field throughout the growing period is recommended for stevia growers under similar agro-ecology with the present study.

Table 3: Mean performance of stevia yield and yield components

\begin{tabular}{|l|l|l|l|l|}
\hline Treatment & PH $(\mathbf{c m})$ & BN (count/plant) & FLYPH(ton) & DLYPH(ton) \\
\hline 1. Weed free for 15DAT & $51.00^{\mathrm{bcd}}$ & $15.33^{\mathrm{bc}}$ & $1.40^{\mathrm{de}}$ & $0.32^{\mathrm{de}}$ \\
\hline 2.Weed free for 30DAT & $54.00^{\mathrm{abc}}$ & $16.33^{\mathrm{b}}$ & $1.33^{\mathrm{de}}$ & $0.34^{\mathrm{de}}$ \\
\hline 3. Weed free for 45DAT & $54.00^{\mathrm{abc}}$ & $17.33^{\mathrm{b}}$ & $1.50^{\mathrm{de}}$ & $0.34^{\mathrm{de}}$ \\
\hline 4. Weed free for 60DAT & $51.33^{\mathrm{bcd}}$ & $17.33^{\mathrm{b}}$ & $1.17^{\mathrm{cde}}$ & $0.37^{\text {cde }}$ \\
\hline 5. Weed free for 75DAT & $48.33^{\mathrm{cd}}$ & $18.67^{\mathrm{b}}$ & $2.3^{\mathrm{cd}}$ & $0.51^{\mathrm{cd}}$ \\
\hline 6. Weed free for 90DAT & $45.00^{\mathrm{d}}$ & $20.00^{\mathrm{b}}$ & $2.57^{\mathrm{c}}$ & $0.59^{\mathrm{c}}$ \\
\hline 7. Weed-infested season & $55.33^{\mathrm{ab}}$ & $8.67^{\mathrm{c}}$ & $1.12^{\mathrm{e}}$ & $0.26^{\mathrm{e}}$ \\
\hline 8. Weedy for 15DAT & $47.67^{\mathrm{cd}}$ & $30.67^{\mathrm{a}}$ & $5.65^{\mathrm{a}}$ & $1.20^{\mathrm{a}}$ \\
\hline 9. Weedy for 30DAT & $49.67^{\mathrm{bcd}}$ & $21.33^{\mathrm{b}}$ & $3.77^{\mathrm{b}}$ & $0.83^{\mathrm{b}}$ \\
\hline 10. Weedy for 45DAT & $47.33^{\mathrm{d}}$ & $19.33^{\mathrm{b}}$ & $1.75^{\mathrm{cde}}$ & $0.43^{\mathrm{cde}}$ \\
\hline 11. Weedy for 60DAT & $59.00^{\mathrm{a}}$ & $16.67^{\mathrm{b}}$ & $1.58^{\mathrm{de}}$ & $0.35^{\mathrm{de}}$ \\
\hline 12. Weedy for 75DAT & $56.00^{\mathrm{ab}}$ & $17.33^{\mathrm{b}}$ & $1.3^{\mathrm{de}}$ & $0.29^{\mathrm{de}}$ \\
\hline 13. Weedy for 90DAT & $55.33^{\mathrm{ab}}$ & $16.00^{\mathrm{b}}$ & $1.23^{\mathrm{e}}$ & $0.27^{\mathrm{e}}$ \\
\hline 14. Weed-free season & $46.68^{\mathrm{d}}$ & $33.33^{\mathrm{a}}$ & $6.10^{\mathrm{a}}$ & $1.21^{\mathrm{a}}$ \\
\hline LSD & 6.45 & 7.15 & 1.00 & 0.22 \\
\hline CV & 7.46 & $22.22^{\mathrm{a}}$ & 22.29 & 25.36 \\
\hline
\end{tabular}

Column followed by the same letter is not significantly different at $\mathrm{P} \leq 5 \%$ level of significance. 


\section{Weed data}

Weed density (plant/m2) was recorded during the experimental period by counting plants of each weed species observed in the net area of each plot and by converting the observed total number of weeds per net area of each plot to $\mathrm{m} 2$ for analysis. Eleven weed species were identified, among which broadleaf weeds were dominated $(72.72 \%)$ followed by grass leaf weeds $(18.18 \%)$ and sedges (9.09) (Figure 1).

Table 4: Analyses of variance for weed density and above ground weed biomass

\begin{tabular}{|c|c|c|c|c|}
\hline \multicolumn{5}{|c|}{ Mean Values } \\
\hline Source & $\mathrm{DF}$ & Weed Density (Plant/M ${ }^{2}$ ) & Fresh weed Biomass per $\mathrm{M}^{2}(\mathrm{~g})$ & Dry Weed Biomass per $\mathrm{M}^{2}(\mathrm{~g})$ \\
\hline REP & 2 & $10.38^{\mathrm{NS}}$ & $5511.19^{*}$ & $344.45^{*}$ \\
\hline TRT & 13 & $28.04^{*}$ & $15058.33^{\text {**** }}$ & $941.14^{* * *}$ \\
\hline Error & 26 & 11.64 & 1128.40 & 70.52 \\
\hline $\mathrm{CV}$ & & 44.77 & 19.53 & 26.12 \\
\hline
\end{tabular}

$\mathrm{NS}=$ not significant; *,**, and *** significant at $\mathrm{P} \leq 0.05, \mathrm{P} \leq 0.01$ and $\mathrm{P} \leq 0.001$ probability levels respectively; $\mathrm{DF}=$ degree of freedom; REP=replication; TRT=Treatment; $\mathrm{CV}=$ Coefficient of variance

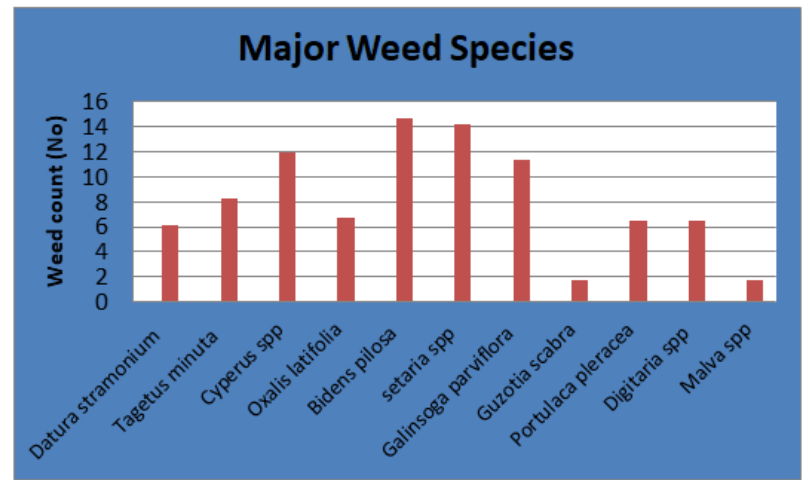

Figure 1: Weed species identified during the experimental period

ANOVA (analysis of variance) showed that treatments significantly affected weed density (Table 4). While the lower significant weed density (4.00) resulted from both weedy for 15DAT and weed-free season, the higher significant weed density (14.00) was obtained from the weed-infested season (Table 5). Likewise, fresh and dry weed biomasses were significantly influenced by treatments (Table 4). The lower significant fresh (69.35g) and dry weed biomasses (11.20g) were obtained from weed-free season treatment while the higher significant fresh (255.28g) and dry (61.65g) weed biomasses were obtained from weed-infested season (no weed control) treatment (Table 5). Though statistically similar among each other the present study showed as treatments such as weed-free for 75DAT, 90DAT as well as weedy for 45DAT, 30DAT, and 15DAT had resulted in lower weed dry biomass next to the weed-free season treatment. The present result is similar to the result of (Alaoui et al., 2003).

Table 5: Mean performance of weed density, fresh and dry weed above ground biomass

\begin{tabular}{|l|l|l|l|}
\hline Treatment & Weed density $\left(\right.$ count $\left./ \mathbf{m}^{2}\right)$ & Fresh weed biomass $(\mathbf{g})$ & Dry weed biomass $(\mathbf{g})$ \\
\hline 1. Weed free for 15DAT & $7.67^{\mathrm{bc}}$ & $246.11^{\mathrm{a}}$ & $58.53^{\mathrm{a}}$ \\
\hline 2.Weed free for 30DAT & $6.33^{\mathrm{bc}}$ & $235.28^{\mathrm{a}}$ & $49.82^{\mathrm{a}}$ \\
\hline 3. Weed free for 45DAT & $9.00^{\mathrm{abc}}$ & $203.01^{\mathrm{a}}$ & $58.84^{\mathrm{a}}$ \\
\hline 4. Weed free for 60DAT & $6.00^{\mathrm{bc}}$ & $209.49^{\mathrm{a}}$ & $52.37^{\mathrm{a}}$ \\
\hline 5. Weed free for 75DAT & $5.00^{\mathrm{c}}$ & $93.15^{\mathrm{b}}$ & $25.25^{\mathrm{b}}$ \\
\hline 6. Weed free for 90DAT & $4.12^{\mathrm{c}}$ & $113.94^{\mathrm{b}}$ & $28.48^{\mathrm{b}}$ \\
\hline 7. Weed-infested season & $14.00^{\mathrm{a}}$ & $255.28^{\mathrm{a}}$ & $61.65^{\mathrm{a}}$ \\
\hline 8. Weedy for 15DAT & $4.00^{\mathrm{c}}$ & $79.58^{\mathrm{b}}$ & $19.90^{\mathrm{bc}}$ \\
\hline 9. Weedy for 30DAT & $6.00^{\mathrm{bc}}$ & $96.39^{\mathrm{b}}$ & $21.10^{\mathrm{bc}}$ \\
\hline 10. Weedy for 45DAT & $9.00^{\mathrm{abc}}$ & $121.99^{\mathrm{b}}$ & $30.50^{\mathrm{b}}$ \\
\hline 11. Weedy for 60DAT & $7.67^{\mathrm{bc}}$ & $220.09^{\mathrm{a}}$ & $51.82^{\mathrm{a}}$ \\
\hline 12. Weedy for 75DAT & $11.67^{\mathrm{ab}}$ & $237.41^{\mathrm{a}}$ & $48.35^{\mathrm{a}}$ \\
\hline 13. Weedy for 90DAT & $11.33^{\mathrm{ab}}$ & $226.57^{\mathrm{a}}$ & $60.24^{\mathrm{a}}$ \\
\hline 14. Weed-free season & $4.00^{\mathrm{c}}$ & $69.35^{\mathrm{b}}$ & $11.20^{\mathrm{c}}$ \\
\hline LSD & 5.72 & 56.38 & 14.00 \\
\hline CV & 44.77 & 19.53 & 26.12 \\
\hline
\end{tabular}

Column followed by the same letter is not significantly different at $\mathrm{P} \leq 5 \%$ level of significance.

\section{SUMMARY AND CONCLUSION}

Stevia is one of the important medicinal plants known globally. In Ethiopia, there registered stevia plant variety so far and there are suitable environmental conditions for the production of the plant in the country. Besides, now proper stevia varieties together with proper management practices are being demanded. Wondogenet agricultural research center is the 
nationally mandated center for medicinal plants research and the current work is part of production package fulfillment work for stevia as production packages were being developed and improved. Weed management practices are very important practices for quantity and quality Therefore, the present study was conducted to find critical weed competition period for stevia growth at Wondogenet agricultural research center during the 2019/2020 cropping season. The experiment was arranged in an RCBD design with three replications having 14 treatments. Stevia plant height, branch number as well as fresh and dry leaf yield were evaluated. All of the evaluated growth and yield parameters were much influenced by the treatments. The longer weed-free period treatments showed significantly shorter stevia plant height and an increase in weed infestation period caused an increase in plant height. This might be due to competition for resources, such as sunlight. Stevia branch number per plant was also influenced by weed interferences for more than 15 days after transplanting. Similar to that of branch number per plant, weed-infested season resulted in lower significant fresh and dry leaf yield per hectare. The present work verified that weeds greatly influenced stevia growth and yield so that identification and use of proper weed management strategy is critical. Besides, weed density and above-ground weed biomass were also evaluated during the experiment. Treatments such as weed-free for seventy-five days after transplanting (75DAT), ninety days after transplanting (90DAT) as well as weedy for forty-five days after transplanting (45DAT), thirty days after transplanting (30DAT), and fifteen days after transplanting (15DAT) had resulted in lower weed dry biomass next to the weed-free season treatment. Therefore, as weeds greatly affect stevia growth and yield, early weeding at 15DAT is important and recommended based on the present finding, however, for comprehensive results the experiment should be repeated over site and year.

\section{REFERENCE}

- $\quad$ Alaoui, B. S., Wyse, D. L., \& Dexter, A. G. (2003). Minimum weed-free period for sugarbeet (Beta vulgaris L.) in the Gharb region of Morocco. Journal of sugar beet research,40(4), p. 251.

- Antonie, A. (2000). Stevia: A plant for sweetness U.S. Pharmacist-A Johnson Publication, (Campbell University School of Pharmacy), vol. 25.

- Bhosle, S. (2004). Commercial Cultivation of Stevia rebaudiana, Agrobios Newsletter, 3(2), 4345.

- Hossain M. F., Islam M. T., Islam M. A., \& Akhtar, S. (2017). Cultivation and Uses of Stevia (Stevia rebaudiana Bertoni): A Review. African Journal of Food, Agriculture, Nutrition and Developmet, 17(4), 12745-12757.

- Prasad, R. D., Singh, R., Prasad, R. P., \& Kumar, S. (2015). Influence of intercropping and weed control methods on growth and yield of maize (Zea mays L.). Research in Environmental and Life Science, 8(1), 37-40.

- Ramesh, K., Singh, V., \& Megeji, N. W. (2006). Cultivation of stevia [Stevia rebaudiana (Bert.) Bertoni]: A comprehensive review. Advances in Agronomy, 89, 137-177.

- Zaman, M. M., Chowdhury, M. A. H., \& Chowdhury, T. (2015). Growth parameters and leaf biomass yield of stevia (Stevia rebaudiana, Bertoni) as influenced by different soil types of Bangladesh. Journal of the Bangladesh Agricultural University, 13(1), 31-37. 